\title{
ISOLASI SENYAWA ALKALOID \\ DARI KULIT BATANG Dehaasia lancifolia BL. Ridl
}

\author{
Hasnirwan ${ }^{1}$, Dayar Arbain ${ }^{2}$, Harry Abrir Effendy ${ }^{1}$ \\ ${ }^{1}$ Laboratorium Kimia Organik Bahan Alam FMIPA Unand \\ ${ }^{2}$ Fakultas Farmasi Unand Padang
}

\begin{abstract}
Dehaasia lancifolia plant from family of Lauraceae and base on the phytochemical survey in Malaysia and West Sumatera containing alkaloid compounds. The alkaloid compounds containing in Dehaasia lancifolia BL. Ridl has not been isolated and from chemotaxonomy aproximation gave an indication that alkaloid structure not quite difference with one of Phoebe genus of the same family wich has been isolated. The isolated alkaloid compound was obtained in amorf solid phase and yellowish colored in relatively high concentration. The bromide salt of this compound melt at $261^{\circ}-264^{\circ} \mathrm{C}$. UV spectrum indicated the maximum absorbtion band at wavelength 282 and $204 \mathrm{~nm}$ wich indicated the chromophoric group of tetrahydroquinoline. IR spectrum shown an absorbtion band at: $3550 \mathrm{~cm}^{-1}$ (stretching C-N), $3030 \mathrm{~cm}^{-1}$ (C-H aromatic), $2930 \mathrm{~cm}^{-1}$ (- $\mathrm{CH}_{2}$ - stretching), 2860 (CH aliphatic stretching), $1660-1600 \mathrm{~cm}^{-1}(\mathrm{C}=\mathrm{C}$ aromatic $), 1530 \mathrm{~cm}^{-1}(\mathrm{C}=\mathrm{N}$ aromatic $), 1070 \mathrm{~cm}^{-1}$ (C-O-C stretching) and brommide salt shown an absorbtion band at $2680 \mathrm{~cm}^{-1}\left(>\mathrm{N}^{+}-\mathrm{H}\right.$ stretching) and without $\mathrm{OH}$ group in this molecule
\end{abstract}

Keywords: dehaasia lancifolia BL. Ridl, alkaloid, spectrophotometer UV and IR

\section{DAFTAR PUSTAKA}

1. A Suplement of Acta Manilana, Phytochemical, Microbiological and Pharmacology Screening of Medicinal Plants, University of Santo Tomas, Manila, Philippines, 1976.

2. Dayar Arbain, A Study of The Alkaloids of Some West Sumatran Plants, Ph.D, Unversity of Western Australia, 1986.

3. G. A. Cordell, Introduction to Alkaloids, A Willey Interscience Publication, John Willey \& Sons, New York, Chichester, Brisbane, Toronto, 1981.

4. Dayar Arbain, and M. V. Sargent, Preliminary Investigation of The Alakloids of Phoobe lanceolata, Asean J. Sci. Technol. Develop., (1987).

5. S. R. John, and J. A. Lamberton, Alkaloids of Phoobe clemensii Allen, Aust. J.Chem., 20: (1967).

6. Shen-Teh $\mathrm{Lu}$, and Ian-Lih Tsai, Two Hexahidroproaporohine Alkaloids,
Lauformine and N-Methyllauformine from Phoobe formosana, Heterocycle, 5, 1984.

7. H.I. Burkill, A Dictionary of The Economic Products of The malay Penisula, Vol. I, Goverment of Malaysia and Sinagapore, The Ministry of Agriculture and Cooperatives, kuala Lumpur, Malaysia, 1966.

8. G. A. Culvenor, and J. S. Fitzegerald, A Field Method for Alkaloids Screening of Plant, J. Pharm. Sci, 52: (1963).

9. J. B. Harborne, Phytochemical Methods, Chapman and Hall, London, 1973.

10. R. H. F. Manske, and H. L. Holmes, The Alkaloid Chemistry and Physiology, Vol. I, Academic Press Inc, New York, 1950.

11. Nordin bin Lajis, Layli bin Din, M. Wahid Samsudin, A. Latief Mohamed, R. Kiew, and R. F. Toia, Aspects of Natural Products Chemistry, Proceeding, The Phytochemical Survey, Departement of Chemistry, Universiti Pertanian Malaysia, Serdang, Selangor, Malaysia, 1885. 
12. B. G. Torssel, Natural product Chemistry, A Mechanistic and Bioynthetic Approach to Secondary Metabolism, John Willey \&
Sons Ltd, Chichester, NewYork, Brisbane, Toronto, Singapore, 1983. 